\title{
A Sustainable Irrigation System for Small Landholdings of Rainfed Punjab, Pakistan
}

\author{
Marjan Aziz ${ }^{1, *(1)}$, Sultan Ahmad Rizvi ${ }^{2}\left({ }^{\circ}\right.$, Muhammad Azhar Iqbal ${ }^{3}$, Sairah Syed ${ }^{4}$, Muhammad Ashraf ${ }^{5}(\mathbb{D}$, \\ Saira Anwer ${ }^{6}$, Muhammad Usman ${ }^{6}$, Nazia Tahir ${ }^{7}$, Azra Khan ${ }^{8}$, Sana Asghar ${ }^{9}$ and Jamil Akhtar ${ }^{1}$ \\ 1 Department of Agricultural Engineering, Barani Agricultural Research Institute, Chakwal 48800, Pakistan; \\ jamilakhtar8231@gmail.com \\ 2 Water Conservation Division, Soil and Water Conservation Research Institute, Chakwal 48800, Pakistan; \\ engrsultan68@yahoo.com \\ 3 Centre of Excellence for Olive Research and Training (CEFORT), Barani Agricultural Research Institute, \\ Chakwal 48800, Pakistan; azhar.horticulture@gmail.com \\ 4 Department of Agronomy, Barani Agricultural Research Institute, Chakwal 48800, Pakistan; \\ sairah81@gmail.com \\ 5 Pakistan Council of Research in Water Resources, Islamabad 44000, Pakistan; \\ muhammad_ashraf63@yahoo.com \\ 6 Faculty of Agricultural Engineering and Technology, Pir Mehr Ali Shah Arid Agriculture University, \\ Rawalpindi 46300, Pakistan; saira.anwer791@gmail.com (S.A.); us.usman791@uaar.edu.pk (M.U.) \\ 7 Department of Agriculture, Abdul Wali Khan University, Mardan 23200, Pakistan; naziatahir@awkum.edu.pk \\ 8 Department of Agronomy, Soil and Water Conservation Research Institute, Chakwal 48800, Pakistan; \\ azrasawcri33@gmail.com \\ 9 Department of Horticulture, Horticultural Research Station, Sahiwal 57000, Pakistan; \\ sanaasghar14@yahoo.com \\ updates \\ Citation: Aziz, M.; Rizvi, S.A.; \\ * Correspondence: marjan_aziz19@hotmail.com; Tel.: +92-332-677-4140
} Iqbal, M.A.; Syed, S.; Ashraf, M.; Anwer, S.; Usman, M.; Tahir, N.;

Khan, A.; Asghar, S.; et al.

A Sustainable Irrigation System for Small Landholdings of Rainfed Punjab, Pakistan. Sustainability 2021, 13, 11178. https://doi.org/10.3390/ su132011178

Academic Editor: Michael S. Carolan

Received: 3 September 2021

Accepted: 30 September 2021

Published: 11 October 2021

Publisher's Note: MDPI stays neutral with regard to jurisdictional claims in published maps and institutional affiliations.

Copyright: (c) 2021 by the authors. Licensee MDPI, Basel, Switzerland. This article is an open access article distributed under the terms and conditions of the Creative Commons Attribution (CC BY) license (https:// creativecommons.org/licenses/by/ $4.0 /)$.

\begin{abstract}
Drip irrigation has long been proven beneficial for fruit and vegetable crops in Pakistan, but the only barrier in its adoption is the high cost of installation for small landholders, which is due to overdesigning of the system. In the present study, the cost of a conventional drip irrigation system was reduced by redesigning and eliminating the heavy filtration system (i.e., hydrocyclon, sand media, disc filters (groundwater source), pressure gauges, water meters, and double laterals).Purchasing the drip system from local vendors also reduced the cost. Field trials were conducted during 2015 and 2016 to observe the productive and economic effects of low-cost drip irrigation on vegetables (potato, onion, and chilies) and fruits (olive, peach, and citrus). The low-cost drip irrigation system saved $50 \%$ cost of irrigation and increased $27-54 \%$ net revenue in comparison with the furrow irrigation system. Further, water use efficiency (WUE) was found from $3.91-13.30 \mathrm{~kg} / \mathrm{m}^{3}$ and $1.28-4.89 \mathrm{~kg} / \mathrm{m}^{3}$ for drip irrigation and furrow irrigation systems, respectively. The physical and chemical attributes of vegetables and fruits were also improved to a reasonably good extent. The present study concluded that low-cost drip irrigation increased the yield by more than $20 \%$, as compared with traditional furrow irrigation, and thus, it is beneficial for the small landholders (i.e., less than 2 hectares).
\end{abstract}

Keywords: agricultural economy; drip irrigation system; net revenue; small landholders; sustainable irrigation

\section{Introduction}

Irrigation, along with other quality inputs, is crucial for the livelihood and food security of Pakistan [1]. Land and water management practices are two very important components to outstrip the water use efficiency and livelihood of rainfed areas [2,3]. In the present system of irrigation, low water use efficiency, and low agricultural productivity are the topmost concerns of the Government of Pakistan [4]. Two possible ways to enhance agricultural productivity include either bringing more area under farming (horizontal expansion) or increasing the production per hectare (vertical expansion) [5]. Historically 
farmers of Pakistan have been using conventional irrigation methods comprising basin, border, and furrow to irrigate the crops, in which the entire fieldis watered without considering the actual crop water requirement. These traditional methods of irrigation have created immense issues such as waterlogging and salinity, and on the other hand, their application efficiency is very low [6]. There are numerous substitute strategies to improve the water application efficiency such as using drip-and-sprinkler irrigation, considering climatic and land parameters, as well as altering the cropping pattern or varieties [4].

Punjab is Pakistan's agro-economic hub that contributes to about 80 percent of the country's food needs [7]. During the last some decades, climate change has had a crucial effect on the country's water resources. In response, progressive farmers started using high-efficiency irrigation systems. Due to their high initial and operational costs, small landholders are constrained to employ these modern technologies due to their poor economic conditions and low potential returns. Modern technologies are necessary to address water scarcity and enhance crop performance and water productivity. The use of high efficiency and low-cost irrigation system is one of many options to overcome the water losses caused by conventional methods [8]. Drip irrigation system, when compared with the furrow irrigation system, gives the optimum potential to enhance yields and irrigation water use efficiency [9]. Evidently, the furrow irrigation system involves a little initial cost, and it appears to be beneficial, but in reality, furrow irrigation systems require vigorous labor for their establishment and need regular maintenance due to having low application efficiency (45\%), as indicated in a study by [10].

Efficient systems such as drip irrigation have been tested in various crops and found to be beneficial in water resources conservation and water productivity enhancement. Many farmers have limited financial resources to install this system. Pakistan is an agricultural country that is currently facing the problem of water scarcity to fulfill different crop requirements. Drip/trickle irrigation technology was introduced in Pakistan during the early 21st century. After years of research and promotion of high-efficiency irrigation systems through subsidized schemes, drip irrigation technology has become available for easy adoption by farmers. Due to high installation costs, less awareness, and training of farmers for its use, this technology still needs to be tested and evaluated at farmer's fields to achieve large-scale farmer adoption [11,12]. Although the subsidized schemes of the government have promoted drip-and-sprinkler technologies, training and knowledge support to farmers for shifting toward high-value cash crops are limiting factors [13]. Farmers worldwide have been using drip irrigation systems since the 1990s, but the trend of adoption is quite moderate in Pakistan for small landholders because of (1) excessive designing, which makes this system very costly for small landholdings and (2) poor management of drip irrigation system.

Keeping in mind the adoption constraints by the small landholders, the current study planned to redesign the system by setting up the simpler parts without the involvement of companies. Hence, the main objectives of this research study were to (1) redesign the system and examine the economics of a low-cost drip irrigation system for small landholders (farmers with lands less than 2 hectares) and (2) compare the drip irrigation system with furrow irrigation in terms of water saving and yield improvement.

\section{Materials and Methods}

The experiment was conducted at Barani Agricultural Research Institute (BARI), which is located at $72^{\circ} 43.4^{\prime}$ longitude, $32^{\circ} 55.5^{\prime}$ latitude, having an altitude of $522 \mathrm{~m}$. The weather conditions of Chakwal are arid to semiarid with annual rainfall varying from 500 to $1000 \mathrm{~mm}$ (1979-2016) [14]. The soil of the experimental site is piedmontalluvial (plains order: ALFISOL belongs to Therpal/Satwal/Kotli series). The physical and chemical properties of the soil as reported [15] are presented in Table 1. 
Table 1. Soil physical and chemical properties of the experimental site.

\begin{tabular}{ccc}
\hline \multirow{2}{*}{ Physical and Chemical Properties of Soil } & \multicolumn{2}{c}{ Depth below Ground Surface } \\
\cline { 2 - 3 } & $\mathbf{0 - 1 5} \mathbf{~ c m}$ & $\mathbf{1 6 - 3 0} \mathbf{~}$ \\
\hline Clay (\%) & 10 & 10 \\
Silt (\%) & 30 & 30 \\
Sand (\%) & 60 & 60 \\
Nitrogen (\%) & 0.8 & 2.0 \\
Phosphorus (ppm) & 5.0 & 3.4 \\
Potassium (ppm) & 138.0 & 132 \\
Organic matter (\%) & 0.6 & 0.33 \\
Electric conductivity (dS/m) & 0.3 & 0.25 \\
pH & 7.68 & 7.79 \\
\hline
\end{tabular}

The trials were set up in a completely randomized block design (RBCD) with two treatments T1 (low-cost drip irrigation) and T2 (conventional furrow irrigation), each having five replications, as shown in Figure $1 \mathrm{a}-\mathrm{d}$. Furrows and ridges were prepared by means of a ridger, keeping the maximum length of furrow as $30 \mathrm{~m}$ to avoid deep percolation losses.

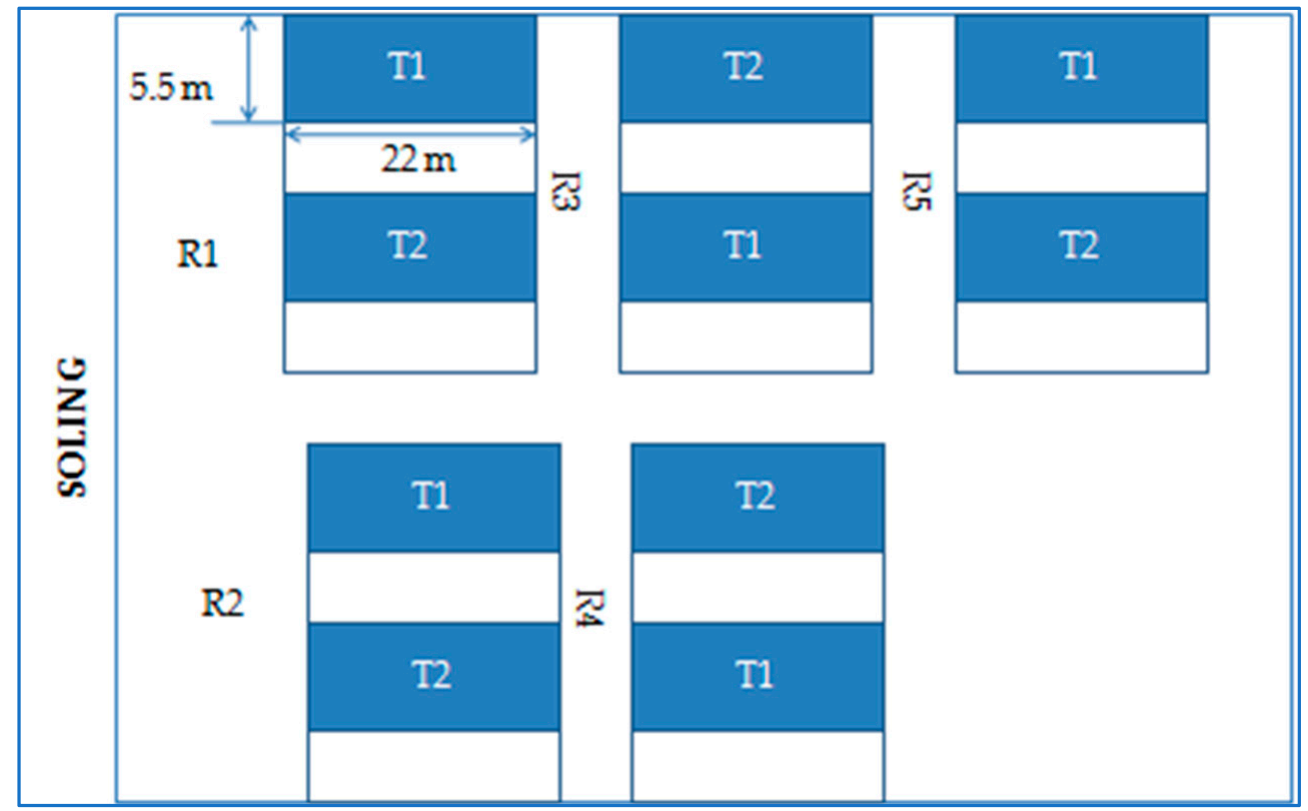

(a)

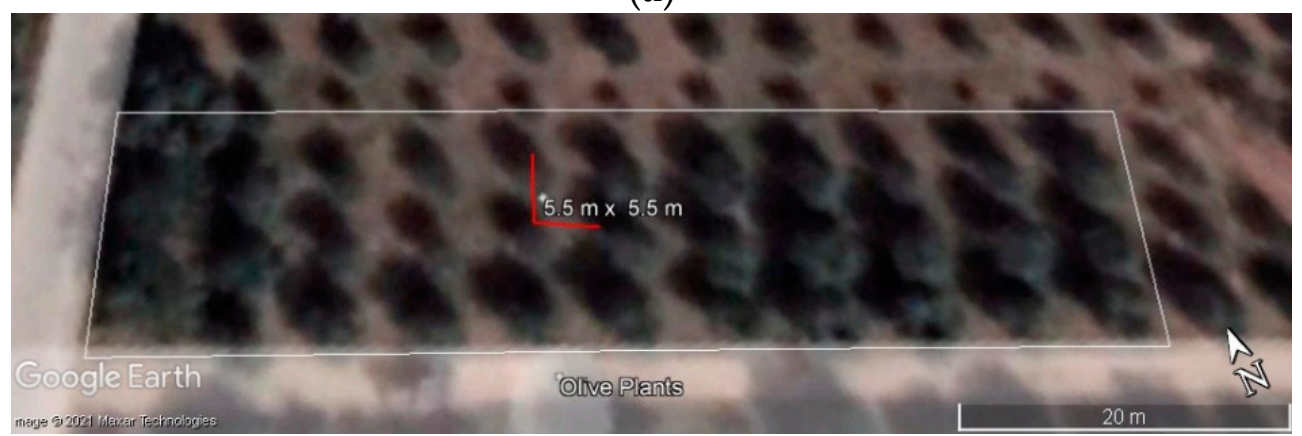

(b)

Figure 1. Cont. 


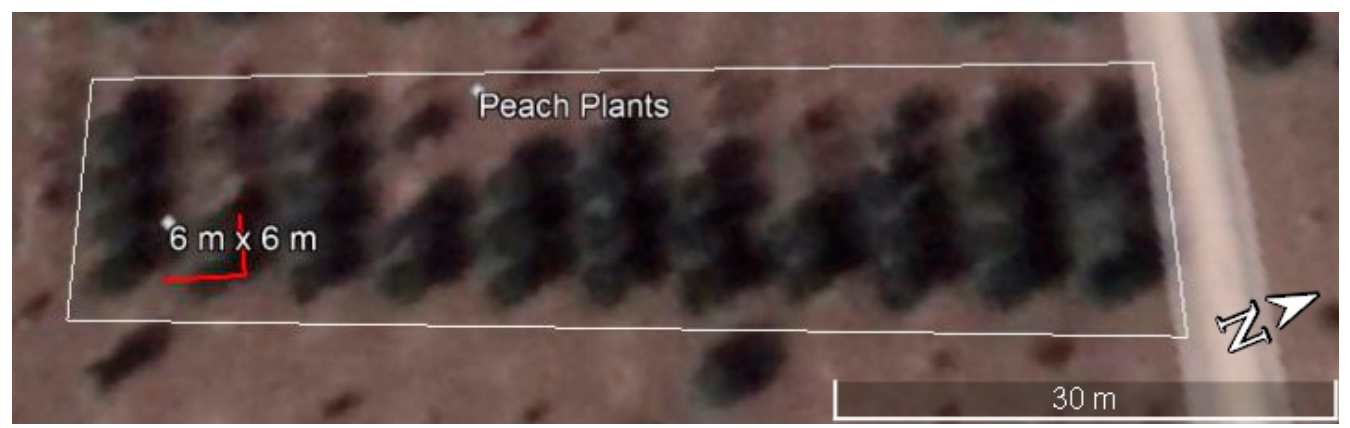

(c)

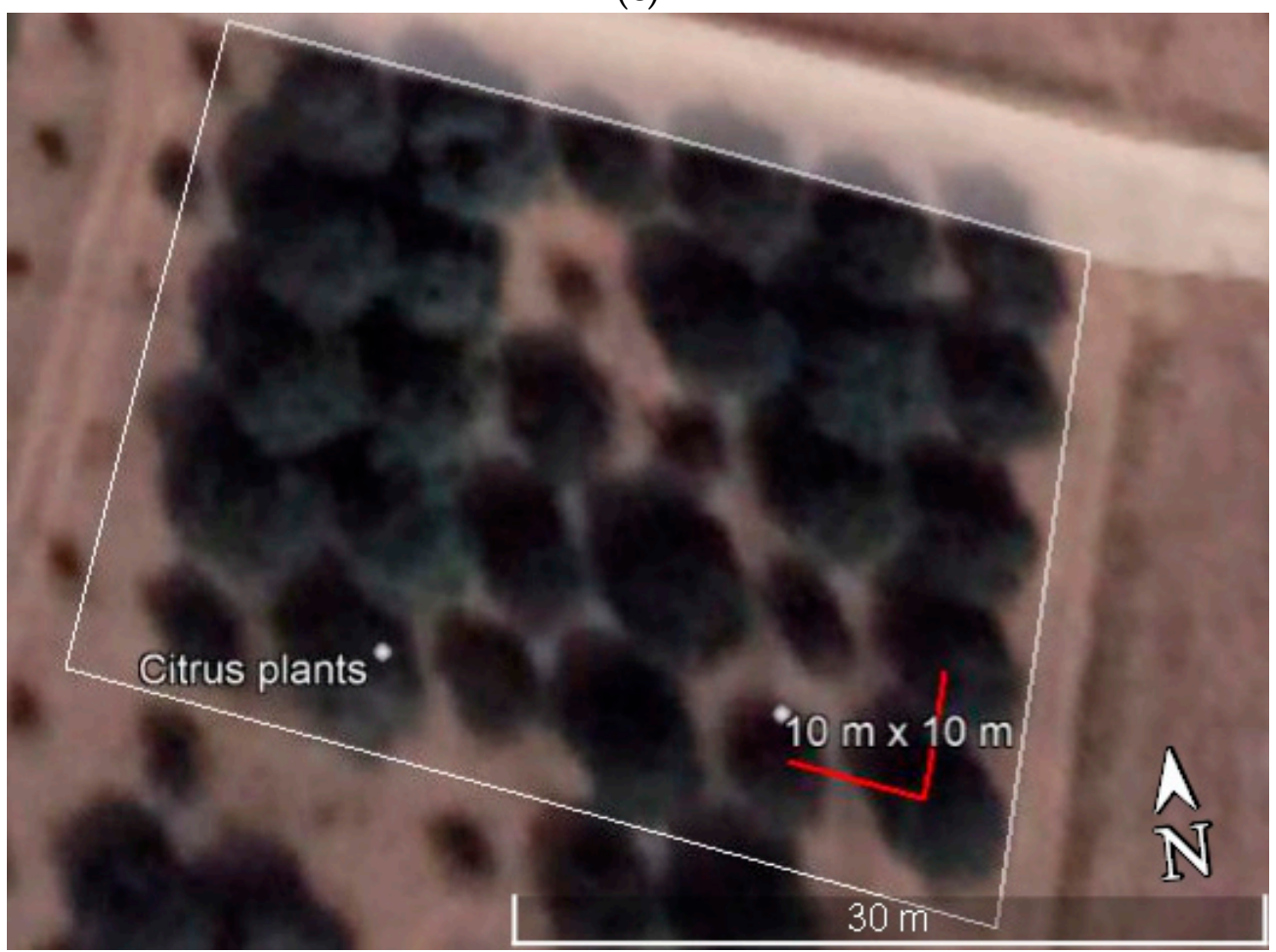

(d)

Figure 1. (a) Block diagram of vegetables (potato, onion, and chilies) plots; (b) the layout of olive plant; (c) the layout of peach plant; (d) the layout of citrus plant.

In Figure 1a, R1, R2, R3, R4, and R5 refer to replications, and T1 and T2 refer to treatments.

Vegetables were sown as per conventional farmers' practice, and plants having age of six years were selected from the existing orchards of BARI, as depicted in Figure $1 \mathrm{~b}-\mathrm{d}$. The planting geometry of vegetables (potato, onion, and chilies) and plants (olive, citrus, and peach) is presented in Table 2.

A low-cost drip irrigation system was designed and installed in the fields manually. This system comprised a main and sub main lines for each set having $38 \mathrm{~mm}$ dia pipe made of polyvinyl chloride (PVC), further attached to lateral lines having $16 \mathrm{~mm}$ dia made of low-density polyethylene (LDPE) fitted with $0.006 \mathrm{~m}^{3} / \mathrm{h}$ drippers (Figure 2). In all crops, lateral lines were placed parallel to the plant lines. Lateral lines with built-in drippers were used for row crops (onion, potato, and chilies), while two (2) drippers/plants were placed on the lateral line for fruit plants (olive, peach, and citrus). The parts of the drip irrigation system were purchased from local vendors (local market) and installed manually (without the involvement of a company). Testing of drippers was performed to check the pressure and flow variations by using the standard method described in [16]. Pressure and flow rates were maintained and recorded as given in Table 3. 
Table 2. Planting geometry of the crops (vegetables and plants).

\begin{tabular}{cccccc}
\hline Crops (Variety Name) & Age of Plant & Row-Row Distance $(\mathbf{m})$ & Plant-Plant Distance $(\mathbf{m})$ & Area/Plant $\left(\mathbf{m}^{2}\right)$ & Total Area under Crop $\left(\mathbf{m}^{2}\right)$ \\
\hline Potato (Desirie) & 1 season & 0.61 & 0.204 & 0.124 \\
Onion (Phulkara) & 1 season & 0.69 & 0.101 & 0.070 \\
Chilies (Ghotki) & 1 season & 0.735 & 0.46 & 0.338 \\
Olive (BARI Zaitoon1) & 6 years & 5.5 & 5.5 & 30 \\
Peach (Early Grand) & 6 years & 6 & 6 & 36 \\
Citrus (Musambi) & 6 years & 10 & 10 & 1220 \\
\hline
\end{tabular}

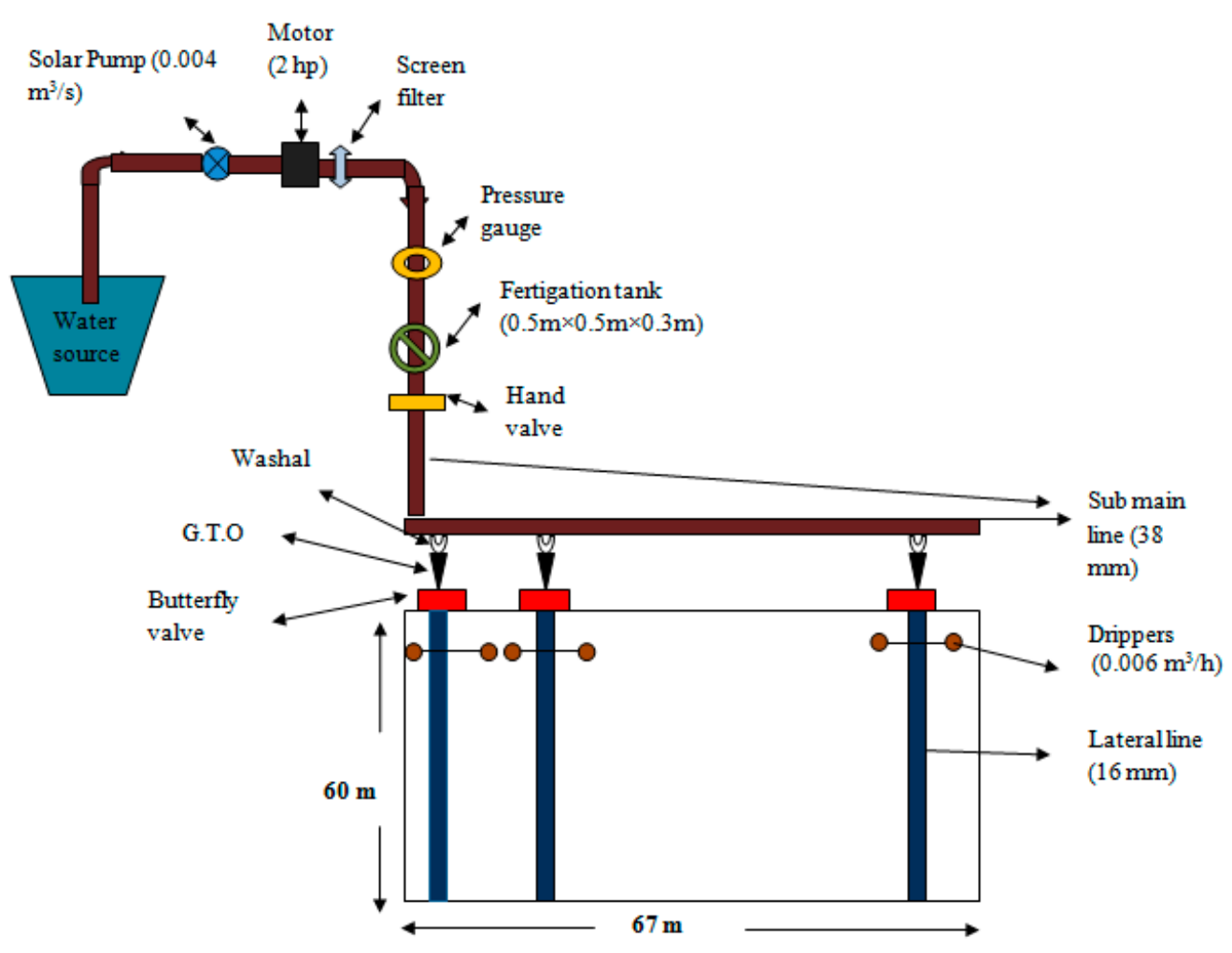

Figure 2. Schematic diagram of the low-cost drip irrigation system.

Table 3. Pressure and flow variation in the low-cost drip irrigation system.

\begin{tabular}{ccc}
\hline Emitter & Pressure (kPa) & Flow Rate $\left(\mathbf{m}^{\mathbf{3}} \mathbf{/ h}\right)$ \\
\hline 1 & 215 & 0.0062 \\
2 & 210 & 0.0063 \\
3 & 210 & 0.0012 \\
4 & 195 & 0.0095 \\
5 & 120 & 0.0064 \\
6 & 190 & 0.0064 \\
7 & 200 & 0.007 \\
8 & 230 & 0.0063 \\
9 & 210 & 0.0064 \\
Average & 197.778 & 0.006 \\
Midpoint & 175 & 0.0101 \\
Variation calculation $(\%)$ & -9 & -11 \\
Acceptable range & $< \pm 10 \%$ & $< \pm 5 \%$ \\
\hline
\end{tabular}

A typical drip system is normally equipped with a venturi injector; including a heavy filtration unit (hydrocyclon filter, sand media filter, and disc filter). However, in the present study, only a screen filter was used at the inlet point of the water source. A simple drum $(0.5 \mathrm{~m} \times 0.5 \mathrm{~m} \times 0.3 \mathrm{~m})$ was placed for fertigation instead of a venturi injector to reduce the cost of the system (Figure 2). The life span of the low-cost drip irrigation system was considered to be 10 years, as adopted by [17]. The solar pump with a flow rate of 
$0.004 \mathrm{~m}^{3} / \mathrm{s}$ was installed for pumping water. The effective life span of the solar pump was assumed to be 30 years, as adopted in [18].

For irrigation scheduling, vacuum-gauge-type tensiometers were installed down to effective root depths. Irrigation applications were scheduled on $60 \%$ soil moisture depletion (SMD) after accounting for effective rainfall. The irrigation requirements of crops were calculated using the moisture retention curve (Figure 3). The effective rainfall was calculated using CROPWAT 8.0 model, as shown in [19].

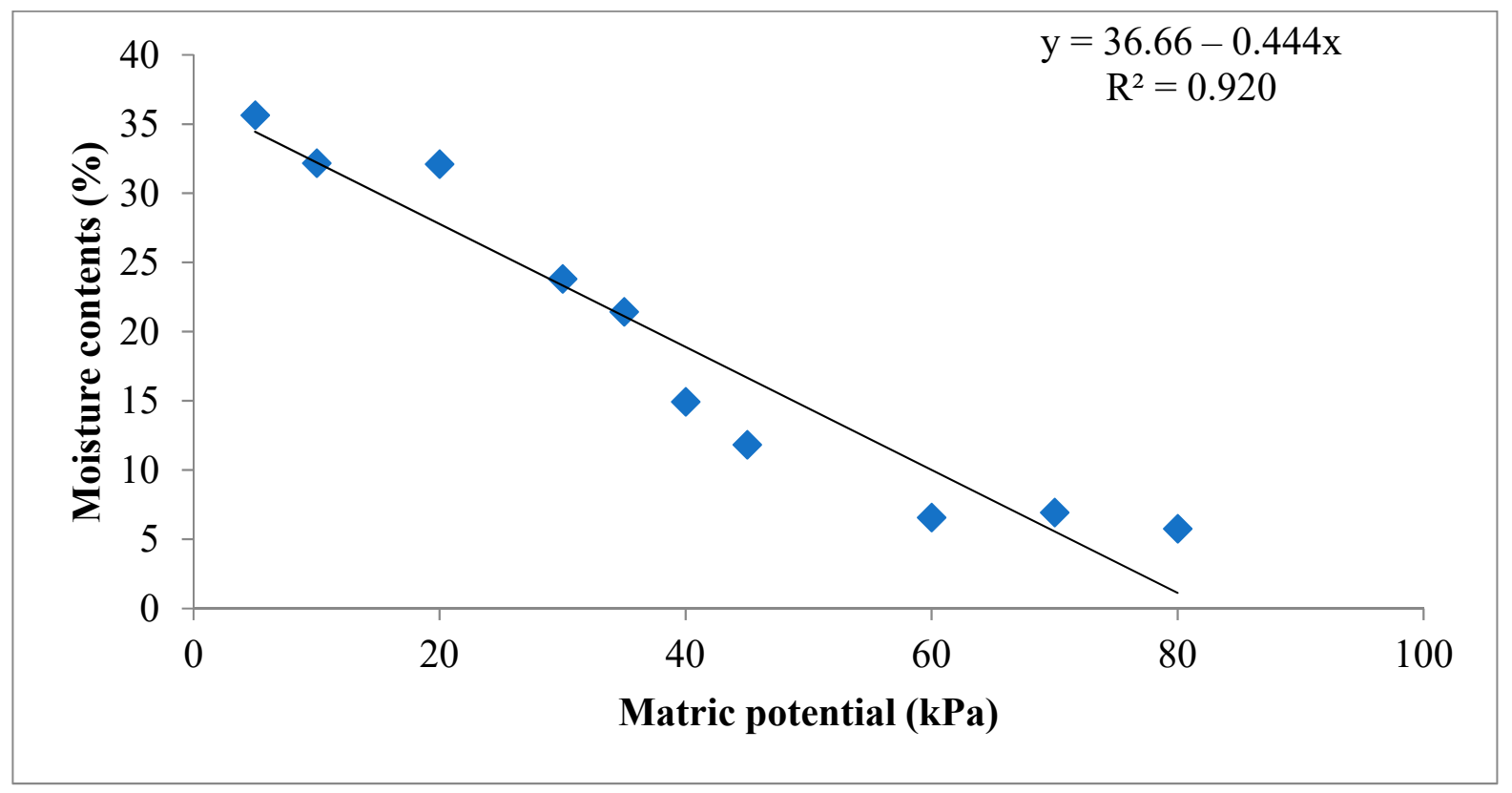

Figure 3. Moisture retention curve.

\subsection{Experimental Data Collection and Analysis}

Pre sowing moisture contents were determined gravimetrically from a depth of $15 \mathrm{~cm}$ to $90 \mathrm{~cm}$, with an interval of $15 \mathrm{~cm}$. To schedule irrigation, soil moisture contents were taken using tensiometers (Figure 3), after 7-day intervals from each of the experimental sets. The seasonal crop water requirements were assessed with the CROPWAT 8.0 model for which input data comprising climate data (maximum and minimum temperatures $\left({ }^{\circ} \mathrm{C}\right.$ ), relative humidity (\%), sunshine hours (hours), wind speed ( $\mathrm{km} /$ day), and rainfall $(\mathrm{mm}))$ were acquired from the nearest weather station installed at the campus, while crop data (planting and harvesting dates, Kc values at each growth stage, root depth (m), plant height (m)) and soil data (soil type, total available water $(\mathrm{mm} / \mathrm{meter})$, maximum rain infiltration rate $(\mathrm{m} /$ day), and initial soil moisture depletion $(\%))$ were recorded on-site.

\subsubsection{Vegetative Growth}

Crops (onion, potato, and chilies) attributes, i.e., plant height (m), root depth (m), and leaf area $\left(\mathrm{m}^{2}\right)$ were measured at the time of harvest. Plant height and root depth were measured from randomly selected 20 plants/replication with the help of a measuring tape. Leaf area $\left(\mathrm{m}^{2}\right)$ was calculated by selecting 5 plants/treatment by separating the leaves from the plant, washed with plain water, and drying them in the open air, using a portable leaf area meter. For fruit trees (olive, peach, and citrus), the plant height $(\mathrm{m})$ and canopy volume $\left(\mathrm{m}^{3}\right)$ were calculated according to the formula: $0.536 \times$ tree height $\times$ crown diameter, as proposed in [20]. 


\subsubsection{Yield}

Yield data of row crops (onion, potato, and chilies) were recorded on each picking from each trial. Similarly, for fruit trees (olive, peach, and citrus), yield data of each fruit tree were measured in $(\mathrm{kg}) /$ tree at the time of each picking.

\subsubsection{Fruit Quality}

Fruit quality was assessed by selecting 20 fruits per treatment at random and determining physical and chemical characteristics of fruit, including fruit length and diameter ( $\mathrm{mm}$ ), fruit weight $(\mathrm{kg}) /$ plant, and its health, with visual observation. Fruit length and diameter were calculated by digital Vernier caliper in the laboratory. A total of 10fruits per replication were selected to record juice quality of citrus and peach such as total soluble solids (TSS) by hand refractometer, titrable acidity (\%), as citric acid according to [21], and juice contents (\%), as proposed in [22]. For all selected crops, the cross-sectional data of fixed costs, variable costs, depreciation costs, and the net return attained during the experimental period 2015-2016 for both drip and furrow irrigation systems were determined.

\section{Results}

\subsection{Water Application}

Water application to a rainfed crop depends on the water availability at the time of sowing and the amount of precipitation received throughout the growing season. For this purpose, long-term rainfall analysis was very important. The weather data for the last 37 years (1979-2016) were collected at the weather station of Soil and Water Conservation Research Institute (SAWCRI), Chakwal, located adjacent to the experimental field, and were analyzed to use in CROPWAT for estimation of crop water requirements. Rainfall data of 2015 and 2016 are shown in Figure 4.

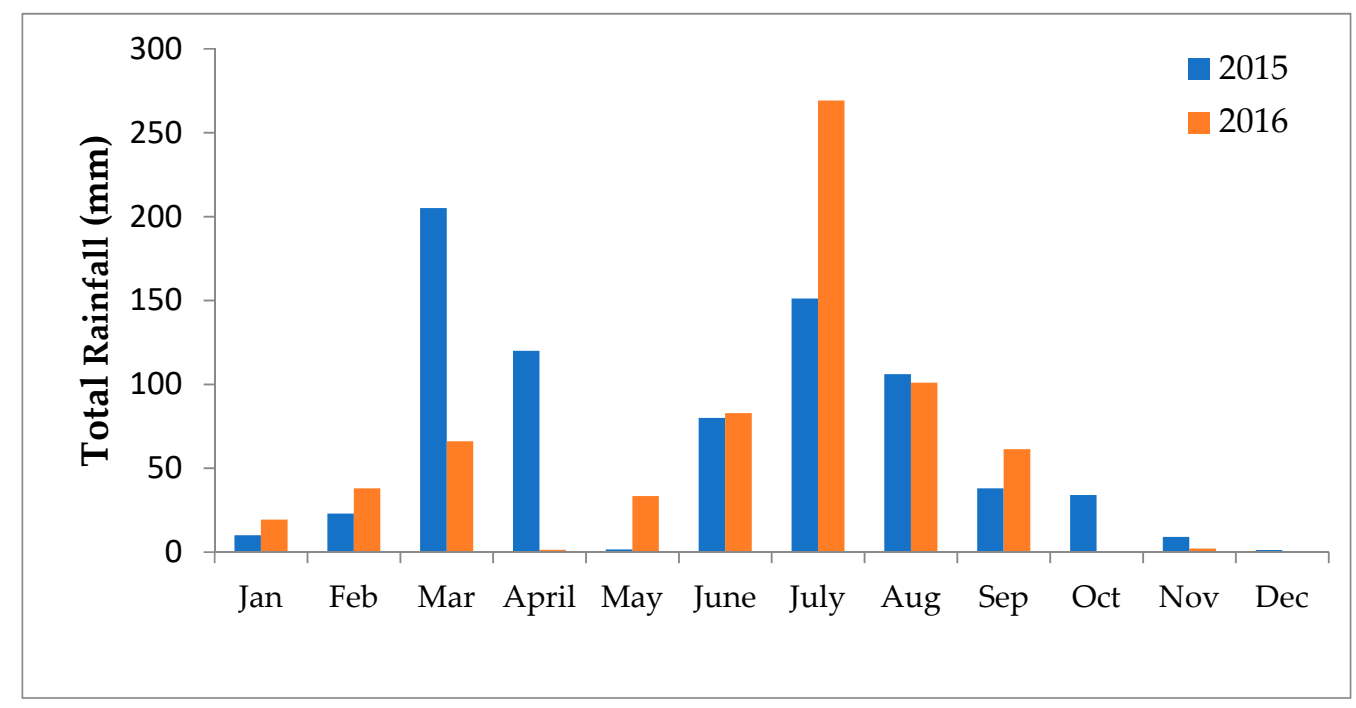

Figure 4. Monthly rainfall $(\mathrm{mm})$ for the experimental period.

Total rainfall during the years 2015 and 2016 was 779 and $675 \mathrm{~mm}$, and effective rainfall was 580 and $502 \mathrm{~mm}$, respectively. The comparison of monthly climatic data with long-term means climatic data showed that total rainfall received during 2015 was higher than in 2016, and $62 \%$ of yearly rainfall was received during the months of July to September in both years. Table 4 shows the amount of effective rainfall and irrigation $\left(\mathrm{m}^{3}\right)$ applied to each crop through drip and furrow irrigation techniques, along with the consequent yield $(\mathrm{kg} / \mathrm{ha})$ and water use efficiency (WUE) values during cropping seasons of 2015 and 2016. 
Table 4. Water and yield data of different crops averaged over two years (2015-2016) at BARI.

\begin{tabular}{|c|c|c|c|c|c|c|c|c|c|c|}
\hline \multirow[t]{2}{*}{ Crop } & \multirow{2}{*}{$\begin{array}{l}\text { Water Requirement } \\
\left(\mathrm{m}^{3} / \mathrm{ha}\right)\end{array}$} & \multirow{2}{*}{$\begin{array}{l}\text { Effective Rain Fall } \\
\qquad\left(\mathrm{m}^{3}\right)\end{array}$} & \multicolumn{2}{|c|}{ Water Applied $\left(\mathrm{m}^{3}\right)$} & \multirow{2}{*}{ Water Saving (\%) } & \multicolumn{2}{|c|}{ Yield (kg/ha) } & \multirow{2}{*}{ Yield Increase (\%) } & \multicolumn{2}{|c|}{$\begin{array}{l}\text { Water Use Efficiency } \\
\text { (WUE) }\left(\mathrm{kg} / \mathrm{m}^{3}\right)\end{array}$} \\
\hline & & & Drip & Furrow & & Drip & $\overline{\text { Furrow }}$ & & Drip & Furrow \\
\hline Potato & 1500 & 280 & 1350 & 2440 & 45 & 10,930 & 7287 & 33 & 8.10 & 2.99 \\
\hline Onion & 2000 & 1060 & 1040 & 1880 & 45 & 13,832 & 9201 & 33 & 13.30 & 4.89 \\
\hline Chilies & 5040 & 3550 & 1660 & 2980 & 44 & 13,049 & 9077 & 30 & 7.86 & 3.05 \\
\hline Olive & 5940 & 4790 & 1280 & 2870 & 55 & 5000 & 3667 & 27 & 3.91 & 1.28 \\
\hline Peach & 7370 & 4790 & 2780 & 6450 & 57 & 25,676 & 19,270 & 25 & 9.24 & 2.99 \\
\hline Citrus & 8480 & 4790 & 4100 & 9220 & 56 & 35,135 & 26,027 & 26 & 8.57 & 2.82 \\
\hline
\end{tabular}

The amount of water applied to each crop was calculated by subtracting the effective rainfall from the total water requirement. Effective rainfall was calculated by using the CROPWAT model, which has the built-in function that uses various parameters, along with total rainfall. Table 4 shows that drip irrigation required $50 \%$ less water, as compared with furrow irrigation, to achieve the required SMD. Moisture levels were kept at an optimal range $(60 \%$ SMD), which improved the plant production and quality. Drip irrigation allowed the rows between plants to remain dry, reduce weed growth, and reduce leaching of water and nutrients below the root zone. The water use efficiency (WUE) values under the drip irrigation system and furrow irrigation system ranged from 3.91 to $13.30 \mathrm{~kg} / \mathrm{m}^{3}$ and $1.28-4.89 \mathrm{~kg} / \mathrm{m}^{3}$, respectively. It was observed that water use efficiency was maximum in onion under drip irrigation $\left(13.30 \mathrm{~kg} / \mathrm{m}^{3}\right)$. The results showed that drip irrigation gave three times more yield per unit of water applied in all vegetables and fruit crops when compared with furrow irrigation. Water use efficiency was exceptionally low in the furrow irrigation system due to conveyance, deep percolation, and evaporation losses. The results of this study are in line with [12], who reported that a low-cost drip system used 30-40\% less water, as compared with the furrow irrigation method. Water savings were also higher (55\%, $57 \%$ and $56 \%$ ) in water-intensive crops such as olive, peach, and citrus, respectively (Figure 5).

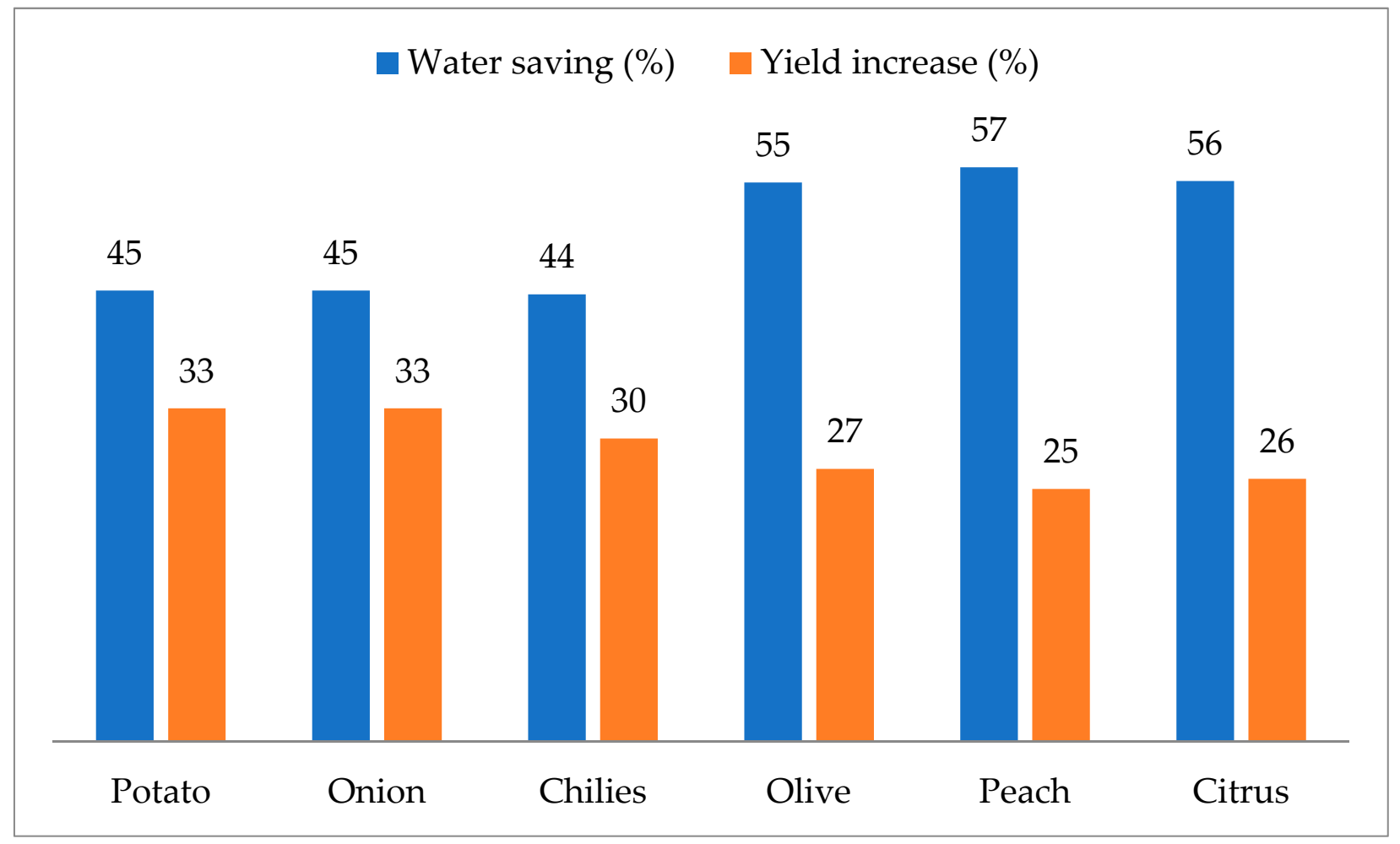

Figure 5. Increase in yield (\%) and water saving (\%) under drip irrigation system, averaged over 2 years (2015 and 2016$).$ 


\subsection{Effect of Irrigation on Physical and Chemical Properties of Fruit}

Values obtained from the treatments related to plant height $(\mathrm{m})$, root depth $(\mathrm{m})$, fruit weight/plant $(\mathrm{kg})$, leaf area $\left(\mathrm{m}^{2}\right)$ for row crops (onion, potato, and chilies) and fruit plants (olive, peach, and citrus) are shown in Table 5, and values of plant height (m), fruit weight/plant $(\mathrm{g})$, canopy volume $\left(\mathrm{m}^{3}\right)$, fruit length $(\mathrm{mm})$, fruit diameter $(\mathrm{mm})$, fruit weight/plant $(\mathrm{kg})$ for fruit plants (olive, peach, and citrus) are given in Table 6.

Table 5. Effect of irrigation treatments on plant attributes of vegetables and fruit plants (averaged over 2 years).

\begin{tabular}{|c|c|c|c|c|c|c|c|}
\hline Parameters/Crops & & Plant Height (m) & Root Depth (m) & Fruit wt./Plant (kg) & Leaf Area $\left(\mathrm{m}^{2}\right)$ & Fruit Length (mm) & Fruit Diameter (mm) \\
\hline \multirow[b]{2}{*}{ Potato } & Drip & 0.6 & 0.33 & 0.391 & 0.2241 & 88 & 55 \\
\hline & Furrow & 0.52 & 0.36 & 0.348 & 0.2012 & 75 & 48 \\
\hline \multirow{2}{*}{ Onion } & Drip & 0.51 & 0.27 & 0.136 & 0.0425 & 65.5 & 70.9 \\
\hline & Furrow & 0.44 & 0.31 & 0.11 & 0.0385 & 59.2 & 62.4 \\
\hline \multirow{2}{*}{ Chilies } & Drip & 0.92 & 0.39 & 0.438 & 0.0475 & 55.5 & \\
\hline & Furrow & 0.85 & 0.42 & 0.347 & 0.0398 & 50.4 & 44.4 \\
\hline \multirow{2}{*}{ Olive } & Drip & 2.1 & 15 & 4.3 & 19.3 & 14.9 & 2.03 \\
\hline & Furrow & 1.9 & 12 & 3.2 & 17.4 & 12.8 & 1.75 \\
\hline \multirow[b]{2}{*}{ Peach } & Drip & 3.5 & 130 & 26.48 & 87 & 6.31 & 116 \\
\hline & Furrow & 3.0 & 100 & 25.2 & 74 & 5.94 & 105.5 \\
\hline \multirow{2}{*}{ Citrus } & Drip & 2.0 & 95 & 9.7 & 66 & 77 & 120 \\
\hline & Furrow & 1.85 & 75 & 8.4 & 62 & 7 & 115 \\
\hline
\end{tabular}

Table 6. Effect of irrigation treatments on chemical parameters of fruit juice (averaged over 2 years).

\begin{tabular}{|c|c|c|c|c|c|c|}
\hline Parameters & \multicolumn{2}{|c|}{ TSS $\left({ }^{\circ}\right.$ Brix) } & \multicolumn{2}{|c|}{ Titratable Juice Acidity (\%) } & \multicolumn{2}{|c|}{ Juice Contents (\%) } \\
\hline Treatments & Drip & Furrow & Drip & Furrow & Drip & Furrow \\
\hline Peach & 5.3 & 3.5 & 0.5 & 0.36 & 48.5 & 46.3 \\
\hline Citrus & 10.3 & 9.56 & 0.45 & 0.3 & 57.5 & 55.2 \\
\hline
\end{tabular}

From the data in Table 5, it is obvious that vegetative growth parameters of all crops (plant height, leaf area, and canopy volume, and fruit wt. $(\mathrm{kg})$ per plant) increased in the treatment of drip irrigation system. The drip irrigation system maintained soil moisture around the plant roots by maintaining the soil physical properties, which could be a possible reason for the enhanced plant growth and yield under drip irrigation. Similar results were reported in [23-25] for potato, onion, and chilies, respectively, and in [26-28] for olive, peach, and citrus, respectively.

The chemical properties of peach and citrus juice were also recorded, as shown in Table 6, which included total soluble salts (TSSs), Brix, titratable juice acidity (\%), and juice contents $(\%)$. Some studies $[20,27]$ reported an increase in TSS and titratable acidity under drip irrigation treatment as the amount of water applied decreased, and in the furrow irrigation system, plants received ample water; thus, the values of fruit juice quality parameters were reduced. The comparative wet conditions that enhanced the fruit size may be conducive for the production of higher total soluble salts (TSSs). High soil moisture levels helped in increasing titratable acidity and juice contents.

\subsection{Economic Evaluation}

The drip irrigation method requires an initial fixed cost for installation, and the cost depends on the crop nature, plant spacing, water requirement, discharge of the dripper, and distance from the water source. The crops with more plant to plant and row to row distance require a relatively low capital cost. Moreover, the fixed cost also depends on the quality of the materials used for the system. In Pakistan, the adoption of drip irrigation systems is quite slow mainly because of overdesigning of the system. In Governmentsponsored subsidized schemes, high-efficiency irrigation systems are generally equipped with solar-powered groundwater pumps, heavy filters, fertigation chambers, etc. Further, many companies are involved in designing (who overdesign in their interest) without good experience, installing the drip system by adding large and unnecessary parts such as filters, gauges, fertigation tanks, water meters, etc., which make the system costly. The management of such systems is difficult for common farmers; therefore, they are reluctant to 
install the system. In this study, the authors proposed a low-cost/economical drip irrigation system by eliminating unwanted parts, purchasing the parts from local vendors, and installing them manually. All costs involved in making furrows and designing/installing the low-cost drip irrigation system are listed in Tables 7 and 8.

Table 7. Fixed costs and depreciation costs of furrow irrigation system.

\begin{tabular}{cccc}
\hline & & Fixed Cost & \multicolumn{2}{c}{$\begin{array}{c}\text { Depreciation Cost (Labor Involved } \\
\text { in Irrigation and Furrow Repairing) }\end{array}$} \\
\cline { 2 - 4 } Crops & $\begin{array}{c}\text { Pumping Cost } \\
\text { Rs/ha }\end{array}$ & $\begin{array}{c}\text { Laser Leveling Cost + 8 Daily } \\
\text { Paid Labor @ 365 Rs/Day } \\
\text { Rs/ha }\end{array}$ & $\begin{array}{c}\text { Ridge Making through Tractor + } \\
\text { 8 Daily Paid Labor @ 365 Rs/Day } \\
\text { Rs/ha }\end{array}$ \\
\hline Potato & 10,033 & 8788 & 7518 \\
Onion & 10,033 & 8788 & 7518 \\
Chilies & 10,033 & 8788 & 0 \\
Olive & 10,033 & 8788 & 0 \\
Peach & 10,033 & 8788 & 0 \\
Citrus & 10,033 & 8788 & 44,834 \\
\hline
\end{tabular}

Table 8. Fixed costs for the drip irrigation system.

\begin{tabular}{ccccc}
\hline \multirow{2}{*}{ Crops } & $\begin{array}{c}\text { Total Cost of the System } \\
\text { (Rs/ha) }\end{array}$ & $\begin{array}{c}\text { Life of the Drip System } \\
\text { (Years) }\end{array}$ & $\begin{array}{c}\text { Pumping Cost of the System } \\
\text { (Rs/ha) }\end{array}$ & $\begin{array}{c}\text { Life of the Solar Pump } \\
\text { (Years) }\end{array}$ \\
\cline { 2 - 5 } & A & B & C & Dixed Cost [(A/B) + (C/D)] \\
\hline Potato & 874,090 & 10 & 118,500 & 30 \\
Onion & 779,468 & 10 & 118,500 & 30 \\
Chilies & 729,211 & 10 & 118,500 & 30 \\
Olive & 106,175 & 10 & 118,500 & 30 \\
Peach & 96,576 & 10 & 118,500 & 31,359 \\
Citrus & 99,342 & 10 & 118,500 & 767 \\
\hline
\end{tabular}

\section{Discussion}

Irrigation was scheduled with respect to effective rainfall events during crop growing seasons. Irrigation scheduling devices (tensiometers) were installed to monitor the soil moisture to schedule the irrigation events. Water saving in drip irrigation (Figure 5) was high because the furrow system is less efficient (50\%), excess amount of water leached down to the groundwater, and consequently, a large amount of irrigation had to be applied to meet the crop water requirement. The findings of this study are in close agreement with [29], for vegetables, and [30] for fruit crops. The data presented in Figure 5 show the percent increase in yield and water saving in the drip irrigation system. Drip irrigation increased production and, at the same time, increased the quality of fruit, reducing shoot growth, as was reported in [28]. Numerous research studies suggested that wetting only $20 \%$ to $50 \%$ of the effective rooting depth of full-grown deciduous fruit trees is adequate to maximize yield, provided enough water is available to meet water requirements during critical periods of fruit development, as proposed in [31]. Plant growth is badly affected when using the furrow irrigation method because after irrigation, soil moisture contents change from saturation to field capacity to dryness, and therefore, plants bear moisture stress before the next irrigation. A minimum interval of irrigation throughout the crop growing season creates water and nutrient balance and ensures optimum growth of the crop.

Figure 6a-e presents the complete comparison of all costs, i.e., fixed costs, variable costs, and depreciation costs, involved in the establishment and operation of furrow and drip irrigation systems. The total cost of installation of drip irrigation per hectare was calculated as Rs 50,000-150,000, assuming 10 years of its useful life, with a payback period of 1-2 years for fruit plants and 3-6 years for vegetables. The fixed capital costs varied for all crops due to variation in plant spacing of the respective crops (Table 2); it included the cost of installation of drip system, along with pumping cost using a solar pump. Fixed costs in furrow irrigation comprised the cost of land leveling through laser leveler and the tractor expenses to make ridges (Table 7). Laser leveling required $4-4.15 \mathrm{~h} /$ acre to level $10 \mathrm{~cm}$ to $15 \mathrm{~cm}$ deep layers of soil. Short-level furrows required accurate field grading, which was performed by machines. The plowing and furrowing were also performed by machines. These operations required skilled labor, fuel, and machinery tools, and all these 
cots added to the fixed costs of the furrow irrigation method (Table 7). The variation in variable costs was mainly due to incurred expenses with the purchase of seeds, fertilizers, pesticides, weedicides, and labor involved in field operations. In the drip irrigation system, the labor cost was half, as compared to the furrow irrigation system, because in furrow irrigation, more labor was required for hoeing, weeding, and watering operations. The drip irrigation system required lower field operations, which also reduced the cost of the system. Depreciation costs in drip irrigation systems include the repair and maintenance of drip parts such as damage or leakage in lateral lines, drip emitter clogging, etc., which was fixed for all crops (Figure 6a). In the furrow irrigation system, the depreciation cost comprised the cost of labor for the repair and maintenance of furrows after every irrigation or a high-rainfall event. Every month during the crop season eight (8) persons were deployed for these operations for a hectare.

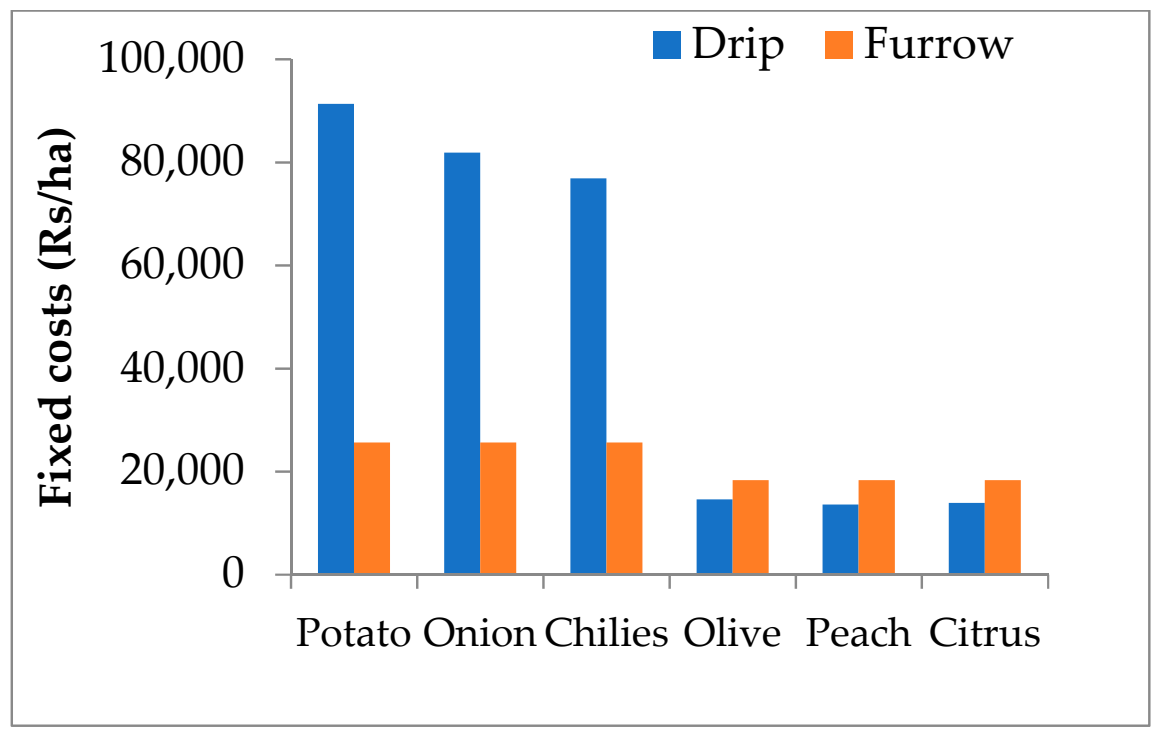

(a)

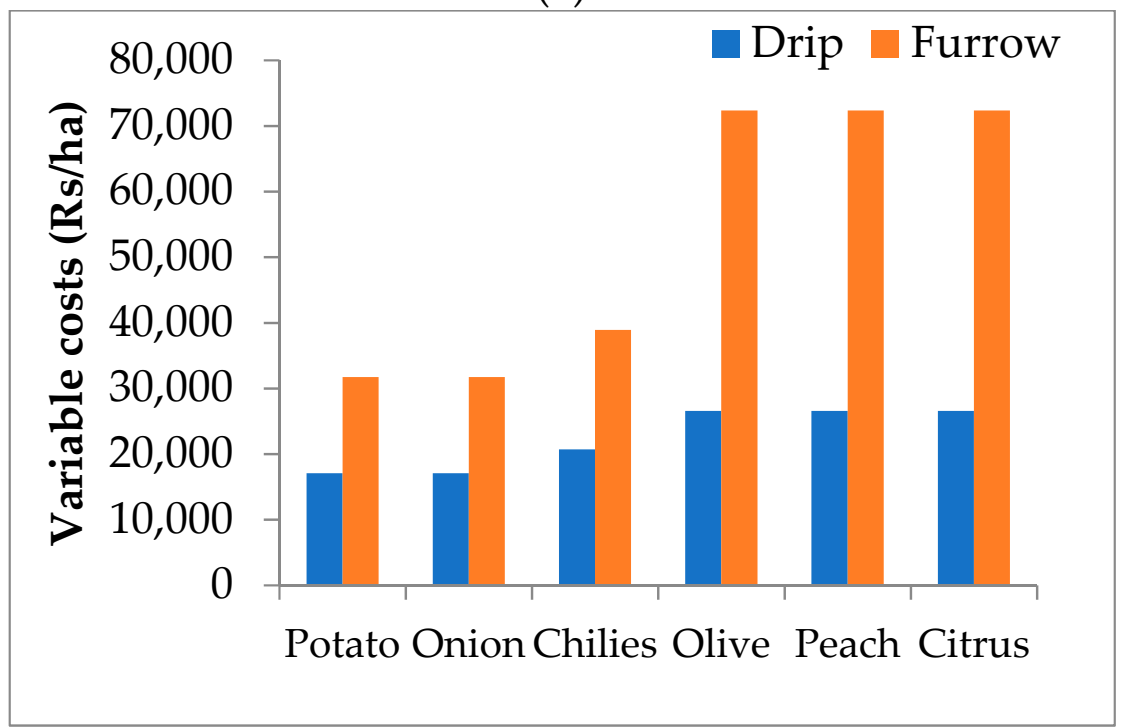

(b)

Figure 6. Cont. 


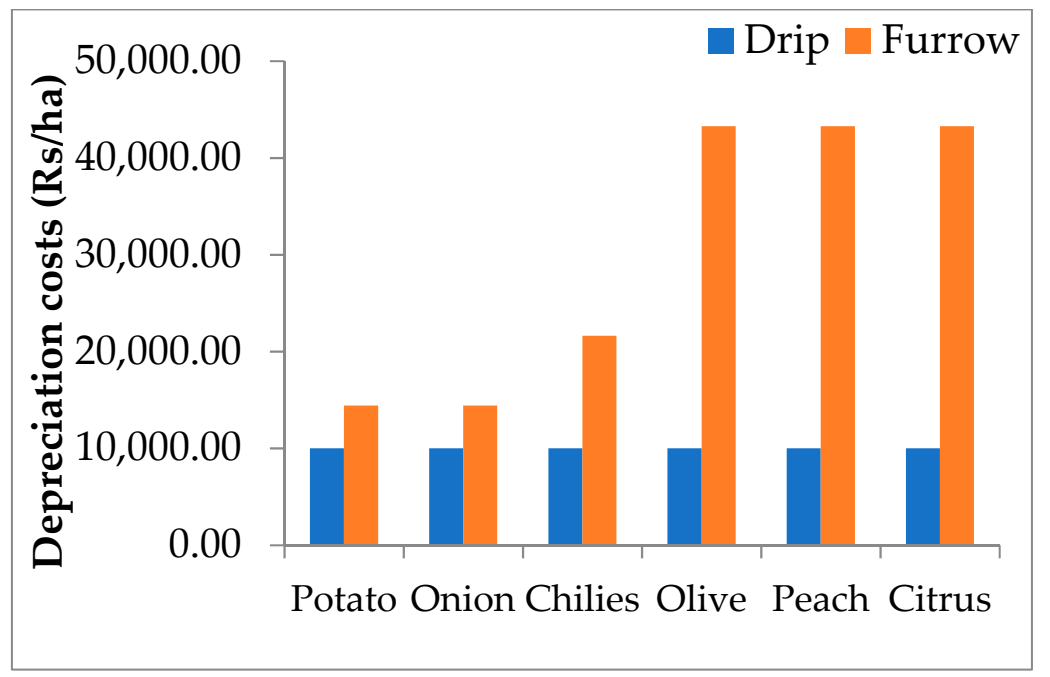

(c)

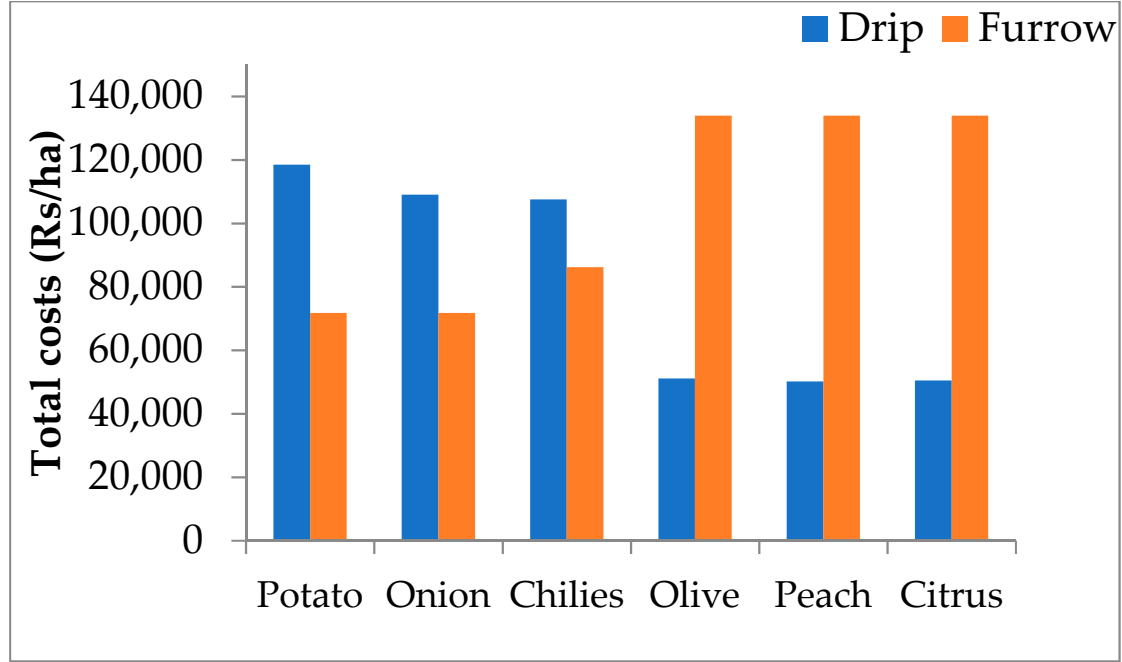

(d)

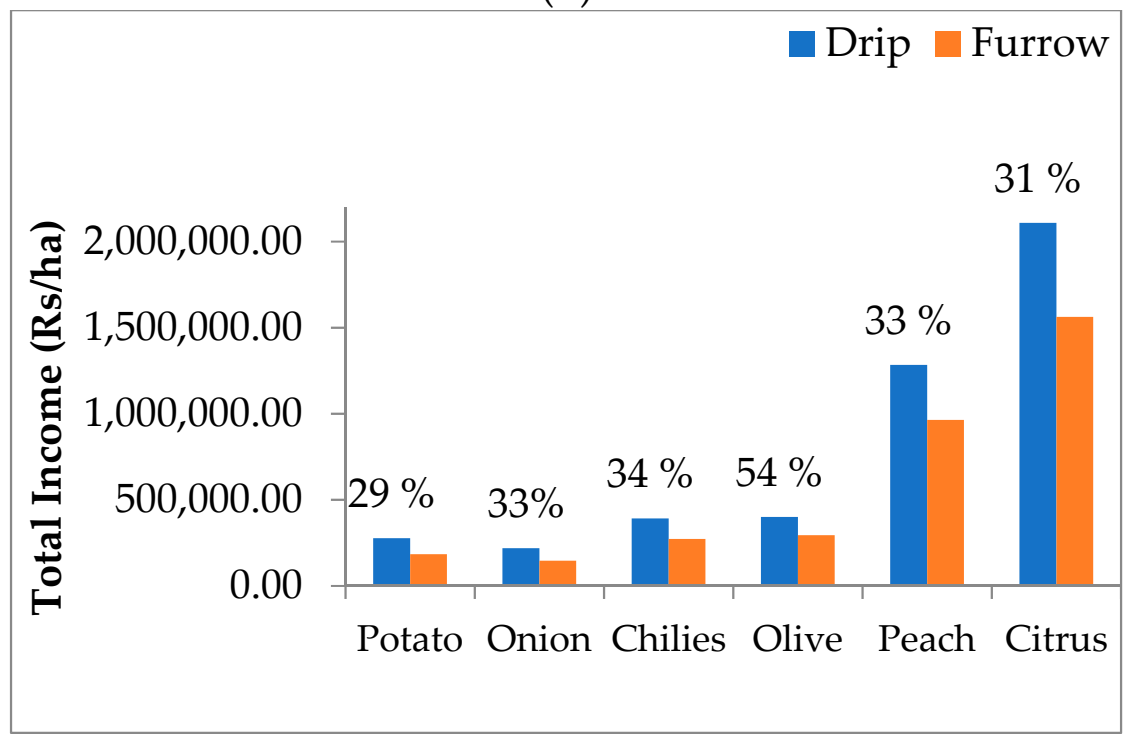

(e)

Figure 6. (a) Comparison of fixed costs incurred in T1 and T2; (b) comparison of variable costs incurred in T1 and T2; (c) comparison of depreciation costs incurred in T1 and T2; (d) comparison of total costs incurred in $\mathrm{T} 1$ and $\mathrm{T} 2 ;$ (e) comparison of total income received from T1 and T2. 
The gross returns were computed by multiplying the average market rate with the yield of respective vegetables and fruits during the crop harvesting period. The seasonal gross expenditure, gross return, net return, and percentage increase in net return for drip irrigation and furrow irrigation systems for all the selected crops are also depicted in Figure $6 \mathrm{~d}$,e. The results revealed that the highest percentage net return per hectare under drip irrigation system was recorded for olive (54\%) and the lowest percentage net returns recorded for potato (29\%), as shown in Figure 6e.

Financial viability analysis was performed by computing the net present value of crops and fruit plants by discounting both the costs and the returns at the prevailing rate of interest (10\%), which is shown in Table 9. From the table, it is clear that net present values of crops and fruit plants were computed for the entire life of the drip system (10 years). Net present values in Table 9 showed that the low-cost drip system discounted cash flows over the entire life of the drip set (10 years). The tear-wise net present worth was estimated to calculate the number of years required to recover the capital cost of the drip system. The payback period for olive, peach, and citrus was 2 years, 1 year, and 1 year, respectively, and for potato, onion, and chilies, the payback period was 5 years, 6 years, and 3 years, respectively. The cost incurred on the drip irrigation system was Rs 118,451 for potato and Rs 108,989 for onion; thus, the payback period for both crops is maximum. Due to narrow plant spacing in potato and onion, the initial costs of drip sets were high.

Table 9. Net present worth and payback periods of drip irrigated crops.

\begin{tabular}{ccc}
\hline Crops & Net Present Value (Rs/ha) @ $\mathbf{1 0} \%$ Discount Rate & Pay Back Period (Years) \\
\hline Potato & 65,247 & 5 \\
Onion & 38,185 & 6 \\
Chilies & 139,032 & 3 \\
Olive & 202,235 & 2 \\
Peach & 746,163 & 1 \\
Citrus & $1,252,415$ & 1 \\
\hline
\end{tabular}

Gross expenditures in the drip irrigation system were higher because of the high initial investment. However, the gross income in the drip irrigation system was high because of the good quality of produce and high yield. Furrow irrigation system consistently underperformed in the case of all the vegetables and fruit crops.

\section{Conclusions}

From the results of this study, it was concluded that the low-cost drip irrigation system applies water near the roots of the plant, as per requirement, and therefore produces more vegetables and fruits with less water. The low-cost drip irrigation under rainfed conditions saved up to $86 \%$ of irrigation water and increased yield by $26-33 \%$, as compared with the furrow irrigation method. Reduced cost of labor in irrigation, fertilizer application, and weeding, combined with increased economic returns, leads to higher economics of vegetable production under the drip system. Fruits and vegetables performed well in the drip irrigation system; however, as observed in this study, the performance of vegetables (potato, onion and chilies) was far low, as compared with fruit plants (olive, peach, and citrus). Based on the present research findings, the average cost of drip sets was calculated to be Rs 50,000-150,000 per hectare for all given crops. It was also concluded that the gross expenditures of the low-cost drip irrigation set can be fully recovered in the second year of crops and orchards. The low-cost drip irrigation was found efficient and economically viable, gave long-term benefits for small landholders, and is feasible/suitable for those areas where the capital costs of existing drip systems are the main barrier to their adoption. There is considerable potential for farmers to grow their orchards and vegetables by installing a low-cost drip irrigation system in their farms/fields. 
Author Contributions: Conceptualization, methodology, execution, data curation, writing-original draft preparation, M.A. (Marjan Aziz); formal data analysis, interpretation of results, review and final revision, S.A.R.; investigation, M.A.I.; resources, S.S.; software, S.A. (Saira Anwer) and S.A. (Sana Asghar); validation, N.T., M.U. and A.K.; acquisition of parts and repair maintenance, J.A.; writing-review and editing, M.A. (Muhammad Ashraf). All authors have read and agreed to the published version of the manuscript.

Funding: This research received no external funding.

Institutional Review Board Statement: Not Applicable.

Informed Consent Statement: Not Applicable.

Data Availability Statement: Not applicable.

Acknowledgments: The authors are indebted to Abdul Majid, ICARDA office in Pakistanfor providing technical guidance and moral help, and Bareerah Fatima from Pakistan Council of Research in Water Resources (PCRWR), Islamabad, is highly acknowledged for her help in completing this study.

Conflicts of Interest: The authors declare no conflict of interest.

\section{References}

1. Government of Pakistan (GoP). Available online: https://www.finance.gov.pk/survey1920.html (accessed on 4 January 2021).

2. Albeyi, A.; Ustun, H.; Oweis, T.; Pala, M.; Benli, B. Wheat water productivity and yield in a cool highland environment: Effect of early sowing with supplemental irrigation. Agric. Water Manag. 2006, 82, 399-410. [CrossRef]

3. Passioura, J. Increasing crop productivity when water is scarce-From breeding to field management. Agric. Water Manag. 2006, 8, 176-196. [CrossRef]

4. Yu, W.; Yi-Chen, Y.; Savitsky, A.; Alford, D.; Brown, C.; Wescoat, J.; Debowicz, D.; Sherman, R. The Indus Basin of Pakistan: The Impacts of Climate Risks on Water and Agriculture; World Bank: Washington, DC, USA, 2013. [CrossRef]

5. Qureshi, S.A. Water management in the Indus basin in Pakistan: Challenges and opportunities. Mt. Res. Dev. 2011, 31, 252-260. [CrossRef]

6. Tagar, A.; Chandio, F.A.; Mari, I.A.; Wagan, B. Comparative study of drip and furrow irrigation methods at farmer's field in Umarkot. Int. J. Agric. Biosyst. Eng. 2012, 6, 788-792.

7. Government of Pakistan GoP. Available online: https://www.finance.gov.pk/survey_1213.html (accessed on 24 November 2019).

8. Mahmood, A.; Oweis, T.; Ashraf, M.; Majid, A.; Aftab, M.; Aadal, N.K.; Ahmad, I. Performance of improved practices in farmers' fields under rainfed and supplemental irrigation systems in a semi-arid area of Pakistan. Agric. Water Manag. 2015, 155, 1-10. [CrossRef]

9. Hanson, B.R.; Hutmacher, R.B.; May, D.M. Drip irrigation of tomato and cotton under shallow saline ground water conditions. Irrig. Drain. Syst. 2006, 20, 155-175. [CrossRef]

10. Irmak, S.; Odhiambo, L.O.; Kranz, W.L.; Eisenhauer, D.E. Irrigation efficiency and uniformity and crop water use efficiency. Biol. Syst. Eng. 2011, 2011, 451.

11. Asif, M.; Ahmad, M.; Mangrio, A.G.; Akbar, G.; Memon, A.H. Design, Evaluation and Irrigation Scheduling of Drip Irrigation System on Citrus Orchard. Pak. J. Meteorol. 2015, 12, 37-48.

12. Razzaq, A.; Rehman, A.; Qureshi, A.H.; Javed, I.; Saqib, R.; Iqbal, M.N. An economic analysis of high efficiency irrigation systems in Punjab, Pakistan. Sarhad J. Agric. 2018, 34, 818-826. [CrossRef]

13. Muhammad, M.; Zahid, A.; Breue, L. Water resources management strategies for irrigated agriculture in the Indus basin of Pakistan. Water 2020, 12, 1429. [CrossRef]

14. Aziz, M.; Tariq, M. Assessing the Potential of Rain-Water Harvesting (in situ) for Sustainable Olive (Oleaeuropaea L.) Cultivation in Water-Scarce Rain-Fed Areas. Irrig. Drain. Syst. Eng. 2018, 7, 212. [CrossRef]

15. Abdul, H.; Yousaf, M. Detailed Soil Survey of Barani Agricultural Research Institute. Chakwal Dir. Soil Surv. Interpret. 1989, (Institutional internal report, unpublished).

16. Zellman, P. Drip Irrigation System Evaluations: How to Measure \& Use Distribution Uniformity Tests Importance of Distribution Uniformity 1-9. 2016. Available online: https://www.sustainablewinegrowing.org/docs/DUArticle.pdf (accessed on 10 May 2018).

17. Reddy, M.; Ayyanagowdar, M.S.; Patil, M.G.; Polisgowdar, B.S.; Nemichandrappa, M.; Anantachar, M.; Balanagoudar, S.R. Water use efficiency and economic feasibility of drip irrigation for watermelon (Citrulluslunatus). Int. J. Pure App. Biosci. 2017, 5, 1058-1064. [CrossRef]

18. Hossain, M.A.; Hassan, M.S.; Ahmmed, S.; Islam, M.S. Solar pump irrigation system for green agriculture. Agric. Eng. Int. CIGR J. 2014, 16, 1-15.

19. FAO. Irrigation water requirements. In Irrigation Potential in Africa: A Basin Approach, Chapter, 5. 2005. Available online: http:/ / www.fao.org/docrep/WRome./w4347e.htm (accessed on 10 March 2017).

20. Verma, N.K.; Lamb, D.W.; Reid, N.; Wilson, B. Comparison of canopy volume measurements of scattered eucalypt farm trees derived from high spatial resolution imagery and lidar. Remote Sens. 2016, 8, 388. [CrossRef]

21. Heising, J.K.; Dekker, M.; Bartels, P.V.; Van Boekel, M.A. Monitoring the quality of perishable foods: Opportunities for intelligent packaging. Crit. Rev. Food Sci. Nutr. 2014, 54, 645-654. [CrossRef] 
22. OECD. Guidance on Objective Tests to Determine Quality of Fruits and Vegetables and Dry and Dried Produce. International Standardization of Fruit and Vegetables. 2005. Available online: https:/ /www.oecd.org/agriculture/fruit-vegetables/publications/ guidelines-on-objective-tests.pdf (accessed on 19 May 2018).

23. Trifonov, P.; Lazarovitch, N.; Arye, G. Water and nitrogen productivity of potato growth in desert areas under low-discharge drip irrigation. Water 2018, 10, 970. [CrossRef]

24. Bagali, A.N.; Patil, H.B.; Guled, M.B.; Patil, V.R. Effect of scheduling of drip irrigation on growth, yield and water use efficiency of onion (Allium cepa L.). Karnataka J. Agric. Sci. 2012, 25, 116-119.

25. Maind, M.M.; Yadload, S.S.; Bhalerao, R.V.; Thalkari, G.N. Effect of Irrigation and Fertilizer Levels on Growth and Yield of Chilli (Capsicum annuum L.). Int. J. Curr. Microbiol. Appl. Sci. 2018, 6, 1192-1199.

26. Karrou, M.; Nangia, V.; Oweis, T. Effect of deficit irrigation on vegetative growth and fruit yield parameters of young olive trees (Oleaeuropaea L.) in semi-arid area of Morocco. In Proceedings of the 7th International Conf. on Water Resources in the Mediterranean Basin, Marrakech, Morocco, 10-12 October 2014.

27. El-sayed, S.A.; Ennab, H.A. Effect of different levels of irrigation water and nitrogen fertilizer on vegetative growth, yield and fruit quality of nitrogen fertilizer on vegetative growth, yield and fruit quality of valencia orange trees. Minufiya J. Agric. Res. 2013, 38, 761-773.

28. Yildirim, O.; Dumanoğlu, H.; Güneş, N.T.; Yildiri, M. Effect of wetted soil area on trunk growth, yield, and fruit quality of drip-irrigated sour cherry trees. Turk. J. Agric. For. 2012, 36, 439-450. [CrossRef]

29. Kumar, R.; Khanna, R. Comparative study of different irrigation methods on tomato crop (Lycopersiconesculentum) in western Uttar Pradesh, India. Int. J. Chem. Stud. 2019, 7, 59-64.

30. Elsayed, M.; Mohammed, A.; Alhajhoj, M.R.; Ali-dinar, H.M.; Munir, M. Impact of a novel water-saving subsurface irrigation system on water productivity, photosynthetic characteristics, yield, and fruit quality of date palm under arid conditions. Agronomy 2020, 10, 1265.

31. Mezghani, M.A.; Mguidiche, A.; Khebour, F.A.; Zouari, I. Water Status and Yield Response to Deficit Irrigation and Fertilization of Three Olive Oil Cultivars under the Semi-Arid Conditions of Tunisia. Sustainability 2019, 11, 4812. [CrossRef] 